\title{
DETECTION OF HUMAN CYTOMEGALOVIRUS AND EPSTEIN-BARR VIRUS IN CORONARY ATHEROSCLEROTIC TISSUE
}

\author{
Ana Vitória Imbronito ${ }^{1}$, Silvia Linardi Marcelino ${ }^{1}$, Sabrina Rosa Grande ${ }^{1}$, Fabio Daumas Nunes ${ }^{2}$, Giuseppe Alexandre \\ Romito ${ }^{1}$
}

${ }^{1}$ Departamento de Estomatologia, Faculdade de Odontologia, Universidade de São Paulo, São Paulo, SP, Brasil; ${ }^{2}$ Departamento de Patologia Bucal, Faculdade de Odontologia - Universidade de São Paulo, São Paulo, SP, Brasil.

Submitted: June 17, 2008; Returned to authors for corrections: November 06, 2008; Approved: March 11, 2010.

\begin{abstract}
Previous studies indicated that patients with atherosclerosis are predominantly infected by human cytomegalovirus (HCMV), but rarely infected by type 1 Epstein-Barr virus (EBV-1). In this study, atheromas of 30 patients who underwent aortocoronary bypass surgery with coronary endartherectomy were tested for the presence of these two viruses. HCMV occurred in $93.3 \%$ of the samples and EBV-1 was present in $50 \%$ of them. Concurrent presence of both pathogens was detected in $43.3 \%$ of the samples.
\end{abstract}

Key words: atherosclerosis; cytomegalovirus; Epstein-Barr virus.

Atherosclerosis, considered the main underlying disease responsible for cardiovascular and cerebrovascular events, has multifactor etiology. Obesity, hyperlipidemia, diabetes, hypertension and cigarette smoking account for 50 to 60 percent of cases of cardiovascular disease (10). Atherosclerosis essentially develops from a mild chronic inflammatory reaction to an injury and there is evidence that infectious microorganisms, such as Chlamydia pneumonia, Helicobacter pylori, periodontal pathogens, human cytomegalovirus (HCMV), hepatitis A virus, enterovirus and Epstein-Barr virus (EBV) may play a pathogenic role $(4,15,20)$.

The latent state of viral infections might differ from that of bacterial infections, and Herpesviridae in particular exert direct proatherogenic effects on injured vessel walls (5). Viruses may directly infect arterial intima, inducing or accelerating atherosclerosis. Moreover, viral infections may promote atherosclerosis by increasing the expression of adhesion molecules and inflammatory cytokines (13) and procoagulant effects (8), and enhancing cholesterol uptake (14) as well as auto-immune response to infection (6). There is experimental evidence that HCMV can infect human coronary smooth muscle cells and initiate viral replication (12), while EBV can have a lifelong persistence in B cells (17). HCMV has been implicated in atherogenesis, and restesnosis after coronary angioplasty and transplant vasculopathy (9). Seroepidemiological studies have implicated EBV in atherosclerosis (19) although only one study detected EBV in atherosclerotic aortic tissue (18).

The objective of the present study was to detect HCMV and EBV-1 in atherosclerotic plaques from patients who underwent coronary endartherectomy.

This study was approved by the Ethical Committee of the Evangélico Hospital (Londrina - Paraná) and all patients signed the informed consent form. Thirty patients (mean age 
$61+11.5$ years, $76.6 \%$ male) with symptomatic coronary artery disease were enrolled. All patients underwent aortocoronary bypass surgery with coronary endartherectomy. An atheroma was taken from each patient's infarct-related artery and the tissue was stored at $-70^{\circ} \mathrm{C}$ with RNAlater $^{\circledR}$ (Applied Biosystems) until DNA extraction. DNA was extracted from each atheroma using Chargeswitch ${ }^{\circledR}$ Gdna Tissue Kits (Invitrogen, São Paulo, Brazil) according to the manufacturer instructions.

Nested-PCR was used to detect viral DNA using specific oligonucleotides for EBV-1 and HCMV. EBV-1 primers amplified a fragment of EBV nuclear antigens EBNA 2 and HCMV primers amplified a fragment of glycoprotein B gene. The outer and inner oligonucleotides primers used in the tests, the temperature of melting and the product length are described in Table 1.

Table 1. PCR primers, temperature of melting (TM) and amplicon length (base pairs) in the identification of the infectious agents

\begin{tabular}{|c|c|c|c|c|}
\hline $\begin{array}{l}\text { Infectious agent } \\
\text { (blast accession) }\end{array}$ & Primer & $\begin{array}{l}\mathrm{TM} \\
{ }^{\mathbf{o}} \mathrm{C}\end{array}$ & $\begin{array}{c}\text { Amplicon } \\
\text { length }\end{array}$ & Reference \\
\hline $\begin{array}{l}\text { Epstein Barr virus } \\
\text { type I } \\
\text { (S71027) }\end{array}$ & $\begin{array}{r}1^{\circ} \text { round 5'-AGGGATGCCTGGACACAAGA-3' } \\
\text { 5'-TGTGCTGGTGCTGCTGGTGG-3' } \\
2^{\circ} \text { round: 5'-AACTTCAACCCACACCATCA-3' } \\
\text { 5'-TTCTGGACTATCTGGATCAT-3' }\end{array}$ & 56 & 602 & 7 \\
\hline $\begin{array}{l}\text { Human } \\
\text { Cytomegalovirus } \\
\text { (X17403) }\end{array}$ & $\begin{array}{r}1^{\circ} \text { round 5' GAGGACAACGAAATCCTGTTGGGCA-3 } \\
\text { 5'-TCGACGGTGGAGATACTGCTGAGG-3' } \\
2^{\circ} \text { round 5'-ACCACCGCACTGAGGAATGTCAG-3' } \\
\text { 5'-TCAATCATGCGTTTGAAGAGGTA-3' }\end{array}$ & 56 & $\begin{array}{l}150 \\
100\end{array}$ & 3 \\
\hline
\end{tabular}

PCR was performed with a final volume of $25 \mu l$ mixture containing 25pmol of each primer (Invitrogen, Carlsbad CA), 1U Taq platinum DNA polymerase (Invitrogen), $50 \mathrm{mM}$ $\mathrm{MgCl}_{2}, 0.05 \mathrm{mM} \mathrm{dNTP}$ mix and 1 to $10 \mu \mathrm{l}$ of extracted DNA sample.

The PCR conditions were optimized for the different primers using as a basis one initial denaturation cycle at $94^{\circ} \mathrm{C}$ for $3 \mathrm{~min}$, followed by 35 cycles of denaturation at $94^{\circ} \mathrm{C}$ for 1 min, annealing at $60^{\circ} \mathrm{C}$ for $1 \mathrm{~min}$ for the first round of EBV-1, at $55^{\circ} \mathrm{C}$ for $1 \mathrm{~min}$ for the second round of $\mathrm{EBV}-1$, at $56^{\circ} \mathrm{C}$ for $50 \mathrm{~s}$ for the first round of $\mathrm{HCMV}$, at $57^{\circ} \mathrm{C}$ for $50 \mathrm{~s}$ for the second round of $\mathrm{HCMV}$, extension at $72^{\circ} \mathrm{C}$ for $1 \mathrm{~min}$, and a final extension step at $72^{\circ} \mathrm{C}$ for $7 \mathrm{~min}$.

All specimens were tested in duplicates to each of the target microorganisms. Negative and positive controls were included in every reaction: DNA free mix as negative control, and DNA from EBV positive cell B lymphoma diagnosed in our laboratory as positive control for EBV. The Laboratory of Virology of University of São Paulo provided the control for HCMV. Detection of PCR products was performed by electrophoresis in a $2 \%$ agarose gel containing $0.5 \mu \mathrm{g} / \mathrm{ml}$ ethidium bromide.

A total of 30 coronary atheroma specimens were investigated. PCR for HCMV yielded positive results for 28 samples (93.3\%), whereas EBV-1 was detected in 15 samples $(50 \%)$. At least one of the viruses was detected in every $\mathrm{C}$. Concurrent infection with HCMV and EBV-1 was observed in 13 specimens (43.3\%) (Table 2).

Table 2. Positivity for Epstein-Barr-1 virus (EBV-1) and human cytomegalovirus (HCMV) in 30 atheroma samples.

\begin{tabular}{lc}
\hline & viral detection \\
\hline EBV-1+/ HCMV - & 2 \\
EBV-1 -/HCMV+ & 15 \\
EBV-1 + /HCMV+ & 13 \\
\hline
\end{tabular}


This study detected DNA from HCMV in most coronary atherosclerotic lesions and indicated that concurrent infection with EBV-1 is also frequent. The high incidence of HCMV in coronary arteries wall of patients suffering from atherosclerosis has also been reported by Hendrix et al. (15), although Shi \& Tokunaga (18) detected HCMV in $40 \%$ of atherosclerotic aortic tissue. In our study, $50 \%$ of the coronary artery atheromas were positive to EBV-1. HCMV DNA in atherosclerotic tissue was reported for the first time by Shi \& Tokunaga (18) in 8 out of 10 atherosclerotic aortic tissues from autopsies.

Most studies implicate HCMV infection with greater risk of accelerated atherosclerosis following heart transplantation (12) and restenosis following coronary atherectomy (22). Grahame-Clarke et al. (11) showed that relatively young asymptomatic individuals seropositive for HCMV have abnormal vascular reactivity consistent with endothelial dysfunction. Their results also suggest that previous HCMV infection might be associated with increased atherosclerotic burden, as assessed by coronary artery calcification. HCMV infection has been shown to upregulate IL-6 gene expression (16) and cytokine production itself (1). Mediated by this systemic inflammatory process, HCMV infection might contribute to the atherosclerotic and atherothrombotic processes, as reported by Blankenberg et al. (2). These authors concluded that HCMV seroposivity in patients with an inflammatory response is independently associated with future cardiac mortality. Since this study detected HCMV in $93.3 \%$ of coronary atheromas, this virus may be strongly implicated in the etiology of atherosclerosis.

Our results indicate that $43.3 \%$ of the samples contained both HCMV and EBV-1 DNA. It has been shown that the aggregate number of pathogens to which an individual had been exposed might be involved in the pathogenesis of atherosclerosis (infectious burden). This concept was demonstrated in cross-sectional as well as prospective studies (5, 23, 24). Rupprecht et al. (20) identified EBV as the strongest independently predictive of future death from cardiovascular causes and showed for the first time that prior infection to EBV may influence the course of atherosclerosis. Herpesviridae in a latent state may contribute to the atherogenic process independently of an inflammatory response. A controlled trial using antiviral substances for the prevention of atherosclerosis and restesnosis after coronary bypass surgery or angioplasty seems justifiable.

This study confirms that HCMV and/or EBV-1 DNA are present in coronary arteries atheromas and the association of both viruses is frequent. Clinical implications of this association and the pathogenic impact on atherosclerosis should be further investigated.

\section{ACKNOWLEDGEMENT}

This study was supported by FAPESP (grant n.04/03199$3)$.

\section{REFERENCES}

1. Almeida, G.D.; Porada, C.D.; St Jeor, S.; Ascencao, J.L. (1994). Human cytomegalovirus alters interleukin-6 production by endothelial cells. Blood. 83(2), 370-376.

2. Blankenberg, S.; Rupprecht, H.J.; Bickel, C.; Espinola-Klein C.; Rippin G.; Hafner G. et al. (2001). Cytomegalovirus Infection With Interleukin6 Response Predicts Cardiac Mortality in Patients With Coronary Artery Disease. Circulation. 103(24), 2915-2921.

3. Darlington, J.; Super, M.; Patel, K.; Grundy, J.E.; Griffiths, P.D.; Emery, V.C. (1991). Use of the polymerase chain reaction to analyse sequence variation within a major neutralizing epitope of glycoprotein B (gp58) in clinical isolates of human cytomegalovirus. J. Gen. Virol. 72, 1985-1989.

4. De Boer, O.J.; Becker, A.E.; van der Wal, A.C. (2003). T-lymphocytes in atherogenesis-functional aspects and antigenic repertoire. Cardiovasc. Res. 60 (1), 78-86.

5. Epstein, S.E.; Zhou, Y.F.; Zhu. J. (1999). Infection and atherosclerosis: emerging mechanistic paradigms. Circulation. 100 (4), e20-28.

6. Epstein, S.E.; Zhu, J.; Burnett, M.S.; Zhou, Y.F.; Vercellotti, G.; Hajjar, D. (2000). Infection and atherosclerosis: potential roles of pathogen burden and molecular mimicry. Arterioscler. Thromb. Vasc. Biol. 20 (6), 1417-20.

7. Espy, M.J.; Smith, T.F. (1995) Comparison of SHARP signal system and Southern blot hybridization analysis for detection of cytomegalovirus in clinical specimens by PCR. J. Clin. Microbiol. 33, 3028-3030.

8. Etingin, O.R.; Silverstein, R.L.; Friedman, H.M.; Hajjar, D.P. (1990). Viral activation of the coagulation cascade: molecular interactions at the 
surface of infected endothelial cells. Cell. 18; 61 (4), 657-662.

9. Fong, I.W. (2000). Emerging relations between infectious diseases and coronary artery disease and atherosclerosis. Canad. Med. Assoc. J. 163 (1), 49-56

10. Fong, I.W. (2002). Infections and their role in atherosclerotic vascular disease. JADA. 133 (Suppl), 7S-13S.

11. Grahame-Clarke, C.; Chan, N.N.; Andrew, D.; Ridgway, G.L.; Betteridge, D.J.; Emery, V., Colhoun H.M.; Vallance, P. (2003). Human cytomegalovirus seropositivity is associated with impaired vascular function. Circulation. 12, 108 (6), 678-683.

12. Gratton, M.T. (1991). Accelerated graft atherosclerosis following cardiac transplantation: clinical perpectives. Clin. Cardiol. 141 (Suppl 2), 16-20.

13. Grundy, J.E.; Downes, K.L. (1993). Up-regulation of LFA-3 and ICAM1 on the surface of fibroblasts infected with cytomegalovirus. Immunology. 78 (3), 405-412.

14. Hajjar, D.P.; Fabricant, C.G; Minick, C.R; Fabricant, J. (1986). Virusinduced atherosclerosis. Herpesvirus infection alters aortic cholesterol metabolism and accumulation. Am. J. Pathol. 1986; 122 (1), 62-70.

15. Hendrix, M.G.; Salimans, M.M.; van Boven, C.P.; Bruggeman, C.A. (1990). High prevalence of latently present cytomegalovirus in arterial walls of patients suffering from grade III atherosclerosis. Am. J. Pathol. $136(1), 23-8$.

16. Iwamoto, G.K.; Konicek, S.A. (1997). Cytomegalovirus immediate early genes upregulate interleukin-6 gene expression. J. Invest. Med. 45 (4), $175-82$.

17. Macsween, K.F.; Crawford, D.H. (2003). Epstein-Barr virus- recent advances. Lancet Infect. Dis. 3 (3), 131-140.

18. Shi, Y.; Tokunaga, O. (2002). Herpresvirus (HSV-1, EBV and CMV) infections in atherosclerotic compared with non-atherosclerotic aortic tissue. Pathol. Int. 52 (1), 31-39.

19. Musiani, M.; Zerbini, M.L.; Muscari, A.; Puddu, G.M.; Gentilomi, G.; Gibellini, D. et al. (1990). Antibody patterns against cytomegalovirus and Epstein-Barr virus in human atherosclerosis. Microbiologica. 13(1). $35-41$.

20. Rupprecht, H.J.; Bickel, C.; Rippin, G.; Hafner, G.; Prellwitz, W.; Schlumberger, W.; Meyer, J. (2001). Impact of viral and bacterial infectious burden on long-term prognosis in patients with coronary artery disease. Circulation. 104(1), 25-31.

21. Speir, F.; Yu, Z.X.; Ferrans, V.J. (1998). Infectious agents in coronary artery disease: viral infection, aspirin and gene expression in human coronary smooth cells. Rev. Port. Cardiol. 17 (Suppl 2), II33-39.

22. Zhou, Y.F.; Leon, M.B.; Waclawiw, M.A.; Popma, J.J.; Yu, Z.X.; Finkel, T. Epstein, S.E. (1996). Association between prior cytomegalovirus infection and the risk of restenosis after coronary atherectomy. N. Engl. J. Med. 29 (335), 624-630.

23. Zhu, J.; Quyyumi, A.A.; Norman, J.E.; Csako, G.; Waclawiw, M.A.; Shearer, G.M.; Epstein, S.E. Effects of total pathogen burden on coronary artery disease risk and C-reactive protein levels. (2000). Am J Cardiol. 85 (2), $140-146$.

24. Zhu, J.; Nieto, F.J.; Horne, B.D.; Anderson, J.L.; Muhlestein, J.B.; Epstein, S.E. (2001). Prospective study of pathogen burden and risk of myocardial infarction or death. Circulation. 103 (1), 45-51. 